\title{
Authenticity and the one-hundred year repair
}

\author{
E. Crocker \\ Crocker Ltd, New Mexico, USA
}

\begin{abstract}
Historic earthen monuments, despite their recognized longevity, can paradoxically be considered fugitive. Unprotected or failing in maintenance even the most massive earthen structures disappear indolently into the ground. It is no surprise that the more craftily constructed and cared-for buildings will far outlast their lesser or neglected brethren. This paper will examine in detail the recent restoration of two Spanish Colonial mission churches in New Mexico, USA, one with massive design flaws dating to the construction era (ca. 1613), and having been subjected to entirely inappropriate "maintenance" after its construction; the other (ca. 1723) subject to benign neglect for nearly one hundred years. In both cases, the goal was to help correct the mistakes of the past and provide a 100year structural repair while complying with the most applicable standards of conservation, based on the directives of the owners. Issues of authenticity as reflected in conservation doctrine will be discussed.

Keywords: New Mexico, colonial churches, authenticity, earth construction, conservation doctrine, seismic vulnerability, seismic performance, adobe maintenance, Native American architecture, non-destructive techniques.
\end{abstract}

\section{Introduction: context and authenticity}

The meeting of the European and Native cultures in North America began in much the same way as colonization anywhere. However, the result of the "encuentro" in what is now the Southwestern United States was somewhat different than the experience elsewhere in North America. Here, rather than the essential displacement of the local population, a process of cultural syncretism began. With varying degrees of success the Spanish implanted their values and their architecture in the colonies. Throughout most of Latin America their old world architectural tradition is apparent. In the Southwest, many values took hold but the physical reflections of them were clearly subsumed by local 
traditions. Baroque-spired, monumental dressed-stone churches made it as far as northern Mexico. North of the Rio Grande, in New Mexico, the churches suddenly become lower, smaller, built of adobe and decidedly reflective of the indigenous puebloan architecture.

The buildings are, on the one hand, fairly static monuments in that at their core they have retained most of their original defining characteristics; on the other hand, they are centuries-old buildings whose message from the past is one that both transcends and trumps their original purpose as places of Roman Catholic worship. The Native communities have for centuries used the churches as ceremonial chambers for Native dances in addition to the celebration of the mass. They have also buried their dead under the floors of the buildings. Of necessity, in most cases, stabilization and conservation activities require excavation and the consequent disturbance of burials.

These circumstances lead to a discussion of authenticity that pits conservation principles for static monuments against living, dynamic buildings. The restoration of the missions at Isleta and Santa Ana Pueblos provides a teachable moment for reviewing the evolution of thinking reflected in doctrinal treatises beginning at the early part of the last century. The case studies also help clarify how the various doctrinal approaches, mostly Euro-centric, work (or do not) when applied in a non-Western context. Finally, these two examples demonstrate unequivocally that, left to their own devices, opinions and values and by retaining total authority over the projects - the tribes did the right thing by any measure.

At the beginning of both projects, the contractor spent many hours with the authorities in both communities discussing their desired approach. In both cases they chose to use no public monies whatsoever, though assistance was available to them, because such funding would invoke compliance with the Secretary of Interior's Standards for the Treatment of Historic Properties.

Among the many difficulties puebloan people have with our nationally mandated standards is the conundrum in Standard 4, which acknowledges change and its importance while the other standards simultaneously enjoin against a continued tradition of change:

"Most properties change over time; those changes that have acquired historic significance in their own right shall be retained and preserved." The Secretary of Interior's Standards for the Treatment of Historic Properties, 1992 [1].

The discussions with tribal officials came down to these conclusions:

- Our worldview embraces a constant state of change.

- The preservation of our traditions is more important than the buildings themselves.

- The present is as important as the past.

- We own the buildings.

In both experiences related here, the tribes wanted value for money spent but, more importantly, they were clear that they wanted to "avoid the same issues" 
for as long as possible, 100 years being the goal. That is conservation philosophy at its core certainly, but the approach had a great deal to do with leaving the burials in and around the buildings undisturbed. It is not realistic to think that one can neglect, however benignly, roofs, flashings and drainage issues for a century; but one can make every effort and that is what was expected.

With those instructions in mind, and absent architects and engineers, restoration began.

\section{Isleta Pueblo: The resurrection of Saint Augustine}

“. . . architecture is necessarily the expression of its age, its development is continuous, and its past, present and future expression must be treated as a whole." Resolutions of the Symposium on the Introduction of Contemporary Architecture into Ancient Groups of Buildings [2].

\subsection{Project background}

The mission of Saint Augustine at Isleta Pueblo, just south of Albuquerque, New Mexico, was built ca.1613, destroyed during the Pueblo Revolt of 1681 and probably remained a ruin until the early 18th century, when it was rebuilt and probably enlarged around 1710. Several iterations occurred subsequently.

In 1959 a very damaging "restoration” was undertaken, during which repairs were made with concrete block and the building was encased in impermeable renders inside and out. A monstrous concrete grade beam was poured around the base of the walls and the belfries were rebuilt in their present configuration.

In early 2010 the Pueblo of Isleta retained Crocker Ltd to restore the building.

\subsection{Restoration}

"We are used to it the way it looks today. Fix it, but on the day you leave, it must look like it did on the day you began.” Frank Lujan, Governor of Isleta [3].

The instructions from Governor Lujan forestalled the issue that often deadlocks architectural conservation projects; no discussions about "taking it back to the original” ensued. The Governor, along with the various committees that were created to plan and oversee the restoration, thus provided the contractor with unequivocal clarity.

In the most substantive way, that is, in appearance, the contractor was able to comply with the "no change" mandate. However, in the interest of convenience, silent and invisible heating and air conditioning systems were retrofitted. The visual integrity of the building was not compromised despite the installation of features that satisfy 21st century occupancy.

The resurrection of St. Augustine took 16 months. Much of that time was spent correcting design flaws dating to the original construction and later interventions. One remarkable feature of the building is that it is actually two structures, one encasing the other. As noted, we believe that the original mission was destroyed and probably remained a ruin until the early 18th century, when reconstruction took place. When select areas were dismantled for restoration it 
became very clear that the original walls - those now on the outside - were about 30 inches thick at the base and 20 feet high. That height-to-thickness ratio with adobe results in serious instability. Somewhere along the line there was either a failure, or the fear of one, and an additional wall was built as an interior veneer.

During excavation along the interior walls to stabilize the base, a large section of the inner veneer collapsed into the trench. The flaw, thus discovered, was that the two walls essentially buttressed one another, but were not mechanically connected. After rebuilding the failed wall, all of the walls of the building were tied together using a technology that is both invisible and reversible.

In the initial phase of the restoration, 375 tons of concrete were removed, mostly dating from the 1959 work. Seventy-five thousand new adobes, plus thousands of salvaged adobes, were used to rebuild the interior wythe of the west wall after the collapse, as well as in other areas. Several months were spent digging through 400 years' worth of successive floors and deposits to reach the original base of the walls. In trenches six feet deep the contractor discovered the original basal wall detail, a mud plastered plinth, that provided the starting point for repairs.

Through it all, discoveries were made that added considerably to the Isletans' knowledge of their mission church. It was discovered that the entire interior of the building was covered in murals that had been buried under successive layers of plaster. After analysis and much discussion, the Pueblo of Isleta determined that the murals could best and most economically be preserved by covering them with yet another coat of mud.

The St. Augustine mission church has been re-dedicated and the restoration wholeheartedly accepted by the community. The infrastructure upgrades are a welcome addition, making the building comfortable year-round and leading to considerably increased use.

\section{Santa Ana de Tamayá: a ceremonial site}

“. . . small settlements are repositories of ways of living which bear witness to our cultures." Report of the Third Inter-American Symposium on the Conservation of Building Heritage [4].

\subsection{Project background}

The Pueblo of Santa Ana de Tamayá, situated just north of Albuquerque, New Mexico, is unique, at least in the Americas, as a non-archeological ceremonial site. The village is isolated and closed to the public except on designated occasions. Nearly all Santa Ana residents reside near the town of Bernalillo but still own homes in Tamayá, which they use almost exclusively for ceremonial occasions.

Santa Ana de Tamayá was founded in 1693; records indicate that by 1696 the building of the first mission church there had begun and that by 1734 the "new" church was near completion [5]. Finished in 1750, the church was dedicated to Saint Anne. Over the course of the intervening centuries the building underwent 
a number of remodels and repairs. Before the restoration reported here, the last major work completed on the church was undertaken in 1923. Since then, there had been steady deterioration as a result of benign neglect.

In 2011, the Pueblo of Santa Ana retained Crocker Ltd to perform a comprehensive restoration of the mission church. Then Lt Governor E. J. Lujan (later Governor) and a committee of tribal members formulated an approach, garnered tribal funds and, over the course of the eleven-month project, directed the work. It was the intent of the committee to remain true to both the style and technologies exemplified in the existing building. To that end, the committee selected two photographs dating to the early 20th century which, combined, provided the architectural format for the restoration. The primary visual consideration was that the second story above the baptistry and the south tower, both of which had been lost, be restored.

\subsection{Restoration}

"People have an instinctive feeling for the value of heritage." The Declaration of Amsterdam [6].

Early on the committee determined that they wanted to remove and not replace the existing exterior cementitious plaster, but rather revert to a traditional earthen render. This decision guided the contractor in designing basal wall and parapet details to assure a long maintenance cycle, while ensuring reversibility and low or no visual impact. This was a clear challenge given, as at Isleta, the goal of a 100-year fix.

In response to the challenge, near-invisible parapet caps were designed and installed; a triple-redundant drainage system and capillarity break were installed at the base of the walls; and a low-maintenance earthen render was designed. It is critical to note that neither the owner nor the contractor would accept chemical amendments to the adobes, the mortar, or the mud plaster. The earthen render on the exterior was designed around locally available materials, those being a high clay content soil and well-sorted, clean aggregates.

Among the major components of the work accomplished at Santa Ana de Tamayá was the complete recordation and removal of every viga and corbel in the building. All were severely rotted where they were embedded in the walls. Using wood epoxy and borate treatments, they were repaired, treated and replaced in their original positions.

The one significant addition made to the old mission was the installation of radiant heat under the new earthen floor. The system is powered by an ondemand propane generator and keeps the floor warm during the winter dances that take place inside the building.

The committee and the contractor met at least every second week to discuss progress and logistics; community members were on site regularly commenting in support of the work and quietly celebrating the "coming home” of Saint Anne. 


\section{Review: context and content}

It is a fascinating exercise to track the intellectual process which, over time, has helped formulate our understanding of the nature of authenticity in architectural conservation. There has been a general tendency away from a strict concentration on material culture, with exceptions, toward acceptance of the human element.

Both of the projects related in this paper were initiated and executed using only local funding and were therefore completely outside the authority of compliance agencies, either federal or state. Given that no external mandates were applicable, how does one assess the "success" of the projects related here in the context of internationally recognized preservation doctrine?

Following is an abstract of some of the more notable doctrines (several of which have been quoted above) that may help us probe the answer to that query.

Table 1: $\quad$ Abstract of charters 1904-1996.

\begin{tabular}{|c|c|c|c|c|}
\hline Year & Place/Sponsor & $\begin{array}{l}\text { Doctrinal } \\
\text { Context }\end{array}$ & Keywords/Concepts & $\begin{array}{l}\text { Authority } \\
\text { Recognized }\end{array}$ \\
\hline 1904 & $\begin{array}{l}\text { Madrid } \\
\text { ICA }\end{array}$ & Global & $\begin{array}{l}\text { Distinguishes between } \\
\text { "dead" and "living" } \\
\text { monuments; comments that } \\
\text { "... utility is one of the } \\
\text { bases of beauty." }\end{array}$ & $\begin{array}{l}\text { Federal } \\
\text { governments }\end{array}$ \\
\hline 1931 & $\begin{array}{l}\text { Athens } \\
\text { Itn’l Museums } \\
\text { Office }\end{array}$ & Global & $\begin{array}{l}\text { Concentrates on } \\
\text { "monuments." Proposes } \\
\text { International Advisory } \\
\text { Organizations and suggests } \\
\text { that decisions are to be } \\
\text { made at the legislative } \\
\text { (national) level; } \\
\text { acknowledges local } \\
\text { circumstance in the } \\
\text { decision-making process. } \\
\text { Emphasis on artistic values. } \\
\text { "Culture" understood to } \\
\text { mean "refined." }\end{array}$ & $\begin{array}{l}\text { Federal } \\
\text { governments }\end{array}$ \\
\hline 1932 & $\begin{array}{l}\text { Rome } \\
\text { Superior Council }\end{array}$ & $\begin{array}{l}\text { National } \\
\text { (Italy) }\end{array}$ & $\begin{array}{l}\text { "Monuments" again the } \\
\text { topic but conservation } \\
\text { criteria, and standards are } \\
\text { addressed with concern } \\
\text { about "forgery" and } \\
\text { "falsification”; touches on } \\
\text { the vernacular by } \\
\text { mentioning "so-called } \\
\text { 'living' monuments"; } \\
\text { "judgement ... not be left } \\
\text { to the personal decision of } \\
\text { the author of the restoration } \\
\text { project." Emphasis on } \\
\text { artistic and aesthetic values. }\end{array}$ & $\begin{array}{l}\text { Superior } \\
\text { Council }\end{array}$ \\
\hline
\end{tabular}


Table 1: $\quad$ Continued.

\begin{tabular}{|c|c|c|c|c|}
\hline Year & Place/Sponsor & $\begin{array}{l}\text { Doctrinal } \\
\text { Context }\end{array}$ & Keywords/Concepts & $\begin{array}{l}\text { Authority } \\
\text { Recognized }\end{array}$ \\
\hline 1964 & $\begin{array}{l}\text { Venice } \\
\text { ICA/UNESCO }\end{array}$ & Global & $\begin{array}{l}\text { Conservation of "monuments" } \\
\text { (again) should be socially useful but } \\
\text { must not alter the message from the } \\
\text { past; respect for original material is } \\
\text { emphasized; falsification in material } \\
\text { must be avoided; "cultural" appears } \\
\text { only as a reference to ICCROM. }\end{array}$ & $\begin{array}{l}\text { “Each } \\
\text { Country” }\end{array}$ \\
\hline \multirow[t]{2}{*}{1967} & $\begin{array}{l}\text { Quito } \\
\text { OAS }\end{array}$ & $\begin{array}{l}\text { The } \\
\text { Americas }\end{array}$ & $\begin{array}{l}\text { Acknowledges that cultural (use of } \\
\text { word ambiguous) heritage can be } \\
\text { "instruments of progress" and be } \\
\text { used in the "cause of ... social } \\
\text { development." Suggests that every } \\
\text { monument was }\end{array}$ & $\begin{array}{l}\text { Federal } \\
\text { governments }\end{array}$ \\
\hline & Quito (con't) & & $\begin{array}{l}\text { designed to fill social function; } \\
\text { emphasis on "western civilization" } \\
\text { with no mention of indigenous } \\
\text { cultures. Emphasis is on } \\
\text { artistic/aesthetic value of European } \\
\text { (Iberian) works. }\end{array}$ & \\
\hline 1972 & $\begin{array}{l}\text { Budapest } \\
\text { ICOMOS }\end{array}$ & Global & $\begin{array}{l}\text { Notes that historic sites reflect } \\
\text { social values and that buildings } \\
\text { must play an active part in today's } \\
\text { life; acknowledges that the past, } \\
\text { present, and future are a "whole"; } \\
\text { endorses the harmonious } \\
\text { introduction of contemporary } \\
\text { architecture in historic zones. } \\
\text { Acknowledges the need to join the } \\
\text { artistic with the social fabric and } \\
\text { needs of the community. }\end{array}$ & Not stipulated \\
\hline 1975 & $\begin{array}{l}\text { The Declaration } \\
\text { of Amsterdam } \\
\text { ( } 2 \text { docs.) } \\
\text { Council of } \\
\text { Europe }\end{array}$ & Europe & $\begin{array}{l}\text { The use of the word "cultural" } \\
\text { becomes less ambiguous; notes the } \\
\text { importance of lesser buildings. } \\
\text { Importantly reflects that "People } \\
\text { have an instinctive feeling for value } \\
\text { of heritage"; introduces phrases such } \\
\text { as "social justice" and "poorer } \\
\text { inhabitants"; suggests responsibility } \\
\text { on multiple levels including } \\
\text { regional, local. Endorses the use of } \\
\text { voluntary associations noting that } \\
\text { groups and individuals make } \\
\text { important contributions. }\end{array}$ & $\begin{array}{l}\text { Council of } \\
\text { Europe, } \\
\text { providing } \\
\text { guidance to } \\
\text { local } \\
\text { authorities }\end{array}$ \\
\hline 1976 & $\begin{array}{l}\text { Nairobi } \\
\text { UNESCO }\end{array}$ & $\begin{array}{l}\text { Global } \\
\text { (member } \\
\text { states) }\end{array}$ & $\begin{array}{l}\text { Promotes the safeguarding of } \\
\text { historic places and endorses the use } \\
\text { of advisory groups and national and } \\
\text { international, non-profit, volunteer } \\
\text { protective organizations. Suggests } \\
\text { the involvement of locals' interests } \\
\text { through practical short courses, } \\
\text { training of artisans and promotion } \\
\text { of traditional crafts. }\end{array}$ & $\begin{array}{l}\text { National, } \\
\text { regional, } \\
\text { local } \\
\text { jurisdictions }\end{array}$ \\
\hline
\end{tabular}


Table 1: $\quad$ Continued.

\begin{tabular}{|c|c|c|c|c|}
\hline Year & Place/Sponsor & $\begin{array}{l}\text { Doctrinal } \\
\text { Context }\end{array}$ & Keywords/Concepts & $\begin{array}{l}\text { Authority } \\
\text { Recognized }\end{array}$ \\
\hline 1982 & $\begin{array}{l}\text { Burra } \\
\text { ICOMOS }\end{array}$ & $\begin{array}{l}\text { Global (by } \\
\text { subscriptio } \\
\mathrm{n} \text { to the } \\
\text { charter) }\end{array}$ & $\begin{array}{l}\text { Introduces the use of the word } \\
\text { "place” in lieu of "monument," } \\
\text { "building” or "site.” Places a strong } \\
\text { emphasis on social values and the } \\
\text { need to understand cultural } \\
\text { significance in the anthropological } \\
\text { sense. Places emphasis on } \\
\text { conservation. }\end{array}$ & $\begin{array}{l}\text { "organization } \\
\{\text { s }\} \text { and } \\
\text { individuals" } \\
\text { (Article 26) }\end{array}$ \\
\hline 1982 & $\begin{array}{l}\text { Tlaxcala } \\
\text { ICOMOS }\end{array}$ & $\begin{array}{l}\text { The } \\
\text { Americas }\end{array}$ & $\begin{array}{l}\text { Theme is small settlements that } \\
\text { reflect “... ways of living which } \\
\text { bear witness." Cultural heritage (no } \\
\text { ambiguity) emphasized; encourages } \\
\text { local knowledge and conservation } \\
\text { of local trades. Comes very close to } \\
\text { drawing the distinction between the } \\
\text { vernacular and the monumental. }\end{array}$ & $\begin{array}{l}\text { States, local } \\
\text { authorities, } \\
\text { communities } \\
\text { share }\end{array}$ \\
\hline 1985 & $\begin{array}{l}\text { Ottawa } \\
\text { ICC-CG }\end{array}$ & Canada & $\begin{array}{l}\text { Reverts to a concentration on } \\
\text { material science and stresses the } \\
\text { physical, historic, and aesthetic } \\
\text { integrity. Refers to quality in } \\
\text { reference to materials and skill. }\end{array}$ & Not stipulated \\
\hline 1993 & $\begin{array}{l}\text { Oaxaca } \\
\text { UNESCO }\end{array}$ & $\begin{array}{l}\text { Ibero- } \\
\text { America }\end{array}$ & $\begin{array}{l}\text { Consideration of globalization as a } \\
\text { conservation issue. "National, } \\
\text { ethnic, cultural, and regional } \\
\text { particularities" are noted. Uses } \\
\text { words such as decolonization, } \\
\text { synthesis, indigenous and plurality } \\
\text { to emphasize the use of heritage as } \\
\text { tool for democracy building. }\end{array}$ & Not stipulated \\
\hline 1994 & $\begin{array}{l}\text { Nara } \\
\text { WHC/ICOMOS }\end{array}$ & Global & $\begin{array}{l}\text { Builds on Venice by stressing } \\
\text { diversity and intellectual richness. } \\
\text { Reminds us of the UNESCO } \\
\text { principle, "the ... heritage of each } \\
\text { is the heritage of all.” Notes that } \\
\text { judgments differ from culture to } \\
\text { culture and so suggests that there } \\
\text { should be no fixed criteria. } \\
\text { Emphasis on information sources } \\
\text { including written, oral, and } \\
\text { figurative. }\end{array}$ & Not stipulated \\
\hline 1996 & $\begin{array}{l}\text { San Antonio } \\
\text { ICOMOS }\end{array}$ & $\begin{array}{l}\text { The } \\
\text { Americas }\end{array}$ & $\begin{array}{l}\text { Seeks to build on Nara; } \\
\text { "restoration" lacks authenticity, } \\
\text { which is only attributable to original } \\
\text { fabric. Notes that the "testimonial” } \\
\text { value of sites is valid (reflecting the } \\
\text { Venice "message from the past.") } \\
\text { Distinguishes memory from } \\
\text { heritage and thus places additional } \\
\text { emphasis on material culture. } \\
\text { Acknowledges the need to } \\
\text { recognize a "multiplicity of values." }\end{array}$ & $\begin{array}{l}\text { National, } \\
\text { regional, } \\
\text { local } \\
\text { jurisdictions }\end{array}$ \\
\hline
\end{tabular}


The iconic Charter of Venice and its derivative United States Secretary of Interior's Standards do not work in Native American contexts because they are materials-centric. To the Native communities of the United States, the materials themselves have little to no intrinsic value. In the words of Ed Ladd of Zuni Pueblo, "We don't dwell on the past, but we don't mind preservation" [7]. He went on to explain that a home, a sacred site or a place of worship does not exist because of the vessel that contains it but because of what happens there.

Thirty years after Venice, the Nara Document on Authenticity proclaimed, "The cultural heritage of each is the cultural heritage of all" [8]. Is that message, which reflects the policy of the UNESCO World Heritage Convention, really appropriate? In an earlier restoration project in which the author was involved, at Acoma Pueblo, he suggested that the massive adobe San Estevan del Rey mission church should be nominated as a World Heritage site. He was told by the Governor, "Let's be clear; this is not world heritage, this is our heritage" [9].

Perhaps the most striking, and appropriate, commentary comes from the earlier declarations. Meeting in Madrid in 1904, The International Congress of Architects acknowledged that "Utility is one of the bases of beauty" [10]. Witness Isleta's response to its challenges by attempting, successfully, to retrofit a 400-year-old building with heating, air conditioning, state of the art audio systems and advanced lighting. The appearance and material content of the building are essentially unchanged, but the beauty of the structure and its appreciation have been unquestionably enhanced by the increased usage it has enjoyed as a result of those utilitarian improvements.

In terms of form, both communities had very clear ideas about change over time. At Isleta, the instructions were crystal clear, paraphrased, "we're used to it the way it looks today.” That approach is valid by any doctrinal standard since 1972 when, in Budapest, it was acknowledged that the past, present and future all contribute to a harmonious whole. At Santa Ana, there was nostalgia for the lost south belfry and the second story over the baptistry, so they chose to replace those two elements and to add heat under the floor. The two architectural elements were a nod to the past but changed the way the building had looked for over a hundred years.

This example raises questions, particularly because the change in appearance occurred well after the building had been placed on the National Register of Historic Places. Had any federal or state monies been involved, compliance with the Secretary of Interior's Standards would have resulted in significant discussions about "change" that the tribe chose to elide. By some measures (The Declaration of San Antonio) the new materials, though local and applied using traditional methods, would have been considered non-authentic [11]. That view stands in clear opposition to the Native consideration of the use of local materials in creating or restoring the vessel which contains the activities that, to them, are the essence of their authenticity. 


\section{Conclusion: authenticity in Native America}

More than a century of thoughtful consideration to the question of how to preserve architectural heritage is reflected in the table above. Perhaps the most salient trend revealed by an analysis is in the meaning, or perhaps more intelligently the implication, of the word "culture." From 1904 in Madrid, through the Charter of Venice in 1964, the use of the word "culture," when it appears, signifies "refined" or "of high artistic and aesthetic value" [12]. The Superior Council in Rome, in 1932, went so far as to declare that decisions of an artistic or aesthetic nature could not fall under the jurisdiction of a local entity [13].

Beginning with the 1967 Organization of American States conclave in Quito, Ecuador, a subtle but very significant transformation in the meaning of the word "culture" begins [14]. Though there is some ambiguity - and a strong tendency toward the Euro-centric concept of the refined - there is a glimmer of response to local culture in the anthropological sense. By the time of the ICOMOS meeting in Burra, Australia in 1982, the ambiguity is gone and "culture" and "cultural" from then on refer to the anthropological meaning [15]. That change certainly benefits the external attitude toward communities such as Santa Ana and Isleta, but it does little to change the compliance issues that have been derived through the doctrine of high culture.

The second most apparent object lesson gleaned from this review is that the recognized authority to whom decisions regarding architectural conservation are left varies wildly from time and place. Here the Burra Charter shines by suggesting that its approach be endorsed voluntarily, by subscription to the philosophy expressed, and that conservation rests with those whose "place" is under consideration. The residents of Isleta and Santa Ana would, I am confident, agree.

Finally, an observation concerning autonomy and authenticity: It is very clear that there is nothing questionable about the success of the restoration of the mission churches in Santa Ana and Isleta; certainly not from their point of view. Placing them within the strictures of both national and international doctrinal compliance, they both still succeed spectacularly. Given that the communities were striving for "the 100-year fix," in order to avoid not just the expense of ongoing structural interventions but the disturbance to human remains, adds another very valid dimension to the projects.

By any measure of compliance with accepted preservation philosophy on a local or global level, the Pueblos of Santa Ana and Isleta met and exceeded all reasonable standards. The lesson is best stated in the Declaration of Amsterdam, "People have an instinctive feeling for the value of heritage."

Particularly their own. 


\section{References}

[1] Morton, W. Brown, Anne E. Grimmer, and Kay D. Weeks. The Secretary of the Interior's Standards for Rehabilitation and Illustrated Guidelines for Rehabilitating Historic Buildings. Washington, D.C.: U.S. Dept. of the Interior, National Park Service, Cultural Resources, Preservation Assistance Division, 1992.

[2] Resolutions of the Symposium on the Introduction of Contemporary Architecture into Ancient Groups of Buildings. Report of the Third General Assembly of ICOMOS in Budapest, 1972.

[3] Lujan, Frank. Governor, Isleta Pueblo, New Mexico, USA. Personal verbal communication, 2010.

[4] The Revitalization of Small Settlements. Report of the Third InterAmerican Symposium on the Conservation of Building Heritage. Tlaxcala, Mexico, 1982.

[5] Kessell, John L. The Missions of New Mexico Since 1776. The University of New Mexico Press, Albuquerque, pp. 166-173, 1980.

[6] The Declaration of Amsterdam. Congress on the European Architectural Heritage, 1975.

[7] Crocker, Edward. Authenticity and Local Knowledge: Conserving the Event. Proceedings of the Interamerican Symposium on Authenticity in the Conservation and Management of the Cultural Heritage of the Americas. US/ICOMOS and the Getty Conservation Institute. San Antonio, Texas, pp. 33-35, 1996.

[8] The Nara Document on Authenticity. Nara Conference on Authenticity in Relation to the World Heritage Convention, Nara, Japan, 1994.

[9] Pasqual, Reginald. Governor, Acoma Pueblo, New Mexico, USA. Personal verbal communication, 1998.

[10] Recommendations of the Madrid Conference. 6th International Congress of Architects. The Architectural Journal: Being the Journal of the Royal Institute of British Architects (RIBA) Vol. XI. Third Series, pp. 343-346, 1904.

[11] Proceedings of the Inter-American Symposium on Authenticity in the Conservation and Management of the Cultural Heritage of the Americas. US/ICOMOS and the Getty Conservation Institute. San Antonio, Texas, pp. ix-xix, 1996.

[12] The Charter of Venice. Second International Congress of Architects and Technicians of Historic Monuments, Venice, 1964.

[13] La Carta Italiana del Restauro 1932. Republished in Carte, Risoluzioni e documenti per la Conservazione ed il Restauro. Pisa, pp. 123-146, 2006.

[14] The Norms of Quito. Final Report of the Meeting on the Preservation and Utilization of Monuments and Sites of Artistic and Historical Value, 1967.

[15] The Burra Charter: The Australia ICOMOS Charter for the Conservation of Places of Cultural Significance, 1982, revised 1999. 